\title{
As Manumissões na Cidade de Pelotas (1832-1849)*
}

\section{Ana Regina Falkembach Simão**}

Durante o passado colonial e imperial brasileiro, as alforrias representaram um dos caminhos mais cobiçados pelos cativos para obterem a liberdade. Desde a Antigüidade até os Tempos Modernos, as manumissões fizeram parte da estrutura escravista. $\mathrm{O}$ próprio direito romano previa alforrias gratuitas e onerosas. ${ }^{1}$

As manumissōes não atenderam apenas aos anseios dos escravos. Serviram também aos senhores, no momento em que lhes permitia "livrar-se de escravos imprestáveis; [a alforria] concedida a prêmio, estimulava a fidelidade de certo tipo de escravos, a exemplo dos domésticos, diante dos quais os senhores eram vulneráveis; constituía uma fonte de renda suplementar derivada do pecúlio dos escravos".2

As cartas de alforria lançadas em Pelotas (1832-1849) ilustram bem esta realidade: "Eu Lina da Conceição Alves viúva de Joaquim Joze Pereira Rabello, atendendo aos bons serviços que me tem prestado a parda Florinda minha escrava pela presente declaro forra e liberta para que como tal seja considerada e possa gozar da proteção das leis como se livre houvesse nascido e para seu título lhe passo a presente carta [...].”3

Existiram alforrias que davam esperanças de uma possível liberdade: "Digo eu Mariana Correia, abaixo assinada que sou senhora, e possuidora de uma escrava Madalena, de nação benguela, sobre a qual atendendo aos bons serviços que me tem prestado, durante o tempo que me tem servido, me resolvo a passar-lhe esta carta de liberdade, com a

\footnotetext{
* Agradecimentos à leitura do Professor Doutor Mário José Maestri Filho.

**Aluna do Curso de Pós-Graduaçăo em História - PUCRS.
} 
condição de servir-me em quanto eu for viva, e bem desempenhar os seus deveres, e depois do dia de minha morte, ficará gozando de sua liberdade $[\ldots] . "{ }^{4}$

A promessa de futura alforria tendia a criar um sentimento de lealdade do escravo para com o senhor. Além deste incentivo a um relacionamento fiel, as manumissões proporcionavam um lucro suplementar ao proprietário, visto que durante o cativeiro a produção do escravo já havia possibilitado a recuperação do investimento feito no momento da compra (inversão inicial). ${ }^{5}$

Muitas vezes, o preço pago por uma alforria equivalia ao valor de um escravo novo. Essa situação acarretava a descapitalização do cativo, em favor do senhor, no momento em que se transformava em um liberto. Em certas ocasiôes, a quantia solicitada era tão alta que se poderia adquirir com ela um imóvel urbano.

A cidade de Pelotas foi, durante o século passado, um centro regional e nacional escravista de importância. Isso devido à produção charqueadora que se realizava principalmente às margens do arroio homônimo. Desenvolveu-se na região e principalmente no município de Pelotas uma sociedade profundamente influenciada pela escravidão. ${ }^{6}$

Em 1833, a cidade de Pelotas tinha 10.873 habitantes, deste total, 5.623 eram escravos, sendo que 1.137 eram libertos, 3.911 brancos e 180 índios. Embora a população escrava masculina fosse significativamente maior do que a feminina, como veremos, no período estudado, constatouse que foram concedidas mais alforrias às mulheres do que aos homens. É sabido que os escravos domésticos desfrutavam de preferências para se tornarem forros, "o que explica, entre outras causas, a maioria de mulheres entre os alforriados"?

TABELA I

População escrava de Pelotas - 1833

\begin{tabular}{lrrlrrr}
\hline & $\mathbf{N}^{\bullet}$ & $\%$ & & $\mathbf{N}^{\bullet}$ & $\%$ & TOTAL \\
\hline Pardos & 186 & 4,8 & Pardas & 268 & 15,8 & 454 \\
Crioulos & 819 & 20,8 & Crioulas & 559 & 33,0 & 1.378 \\
Africanos & 2.925 & 74,4 & Africanas & 866 & 51,2 & 3.791 \\
\hline TOTAL & 3.930 & 100 & TOTAL & 1.693 & 100 & 5.623 \\
\hline
\end{tabular}


TABELA II

População Branca de Pelotas - 1833

\begin{tabular}{|c|c|c|c|c|c|c|}
\hline Estrangeiros & $\mathbf{N}^{\bullet}$ & $\%$ & Brasileiros & $\mathrm{N}^{\bullet}$ & $\%$ & TOTAL \\
\hline Homens & 316 & 15 & Homens & 1.800 & 85,0 & 2.116 \\
\hline Mulheres & 62 & 3,4 & Mulheres & 1.753 & 96,6 & 1.815 \\
\hline TOTAL & 378 & & TOTAL & 3.553 & & 3.911 \\
\hline
\end{tabular}

FONTE: Autoridades Municipais-Câmara Municipal de Pelotas. Local - AHRGS.

TABELA III

População liberta de Pelotas até o ano de 1833

\begin{tabular}{|c|c|c|c|c|c|c|}
\hline Homens & $\mathbf{N}^{\bullet}$ & $\%$ & Mulheres & $\mathbf{N}^{\bullet}$ & $\%$ & TOTAL \\
\hline Pardos & 407 & 75 & Pardas & 436 & 73,2 & 843 \\
\hline Pretos & 135 & 25 & Pretas & 159 & 26,8 & 294 \\
\hline TOTAL & 542 & 100 & TOTAL & 595 & 100 & 1.137 \\
\hline
\end{tabular}

FONTE: Autoridades Municipais - Cãmara Municipal de Pelotas. Local - AHRGS.

\section{TABELAIV}

Porcentagem da população escrava, branca, liberta e indigena de Pelotas - 1833

\begin{tabular}{lcccc}
\hline População & Escrava & Branca & Liberta & Indigena \\
\hline & $51,7 \%$ & $36 \%$ & $10,4 \%$ & $1,6 \%$ \\
\hline
\end{tabular}

FONTE: Autoridades Municipais - Cåmara Municipal de Pelotas. Local - AHRGS.

Na cidade de Pelotas, nos primeiros anos da década de 1840 , comprava-se um terreno, em uma rua bem situada, no perímero urbano, pelo valor de oitocentos mil-réis. Nos livros de transmissōes do $1^{2}$ Tabelionato de Pelotas, encontram-se vários registros de compra de imóvel: Venda de um terreno de dez braças, na rua Augusta, por preço de oitocentos mil-réis; venda de uma morada de casa térrea, por preço de quinhentos mil-réis; venda de um terreno de três braças de frente, na rua 
São Miguel, por setecentos e oitenta mil-réis. ${ }^{8}$ Tais quantias eram comumente oferecidas, por uma manumissão, na mesma cidade.

\section{TABELAV}

Preços de imóveis e de escravos em Pelotas

(1832-1849)

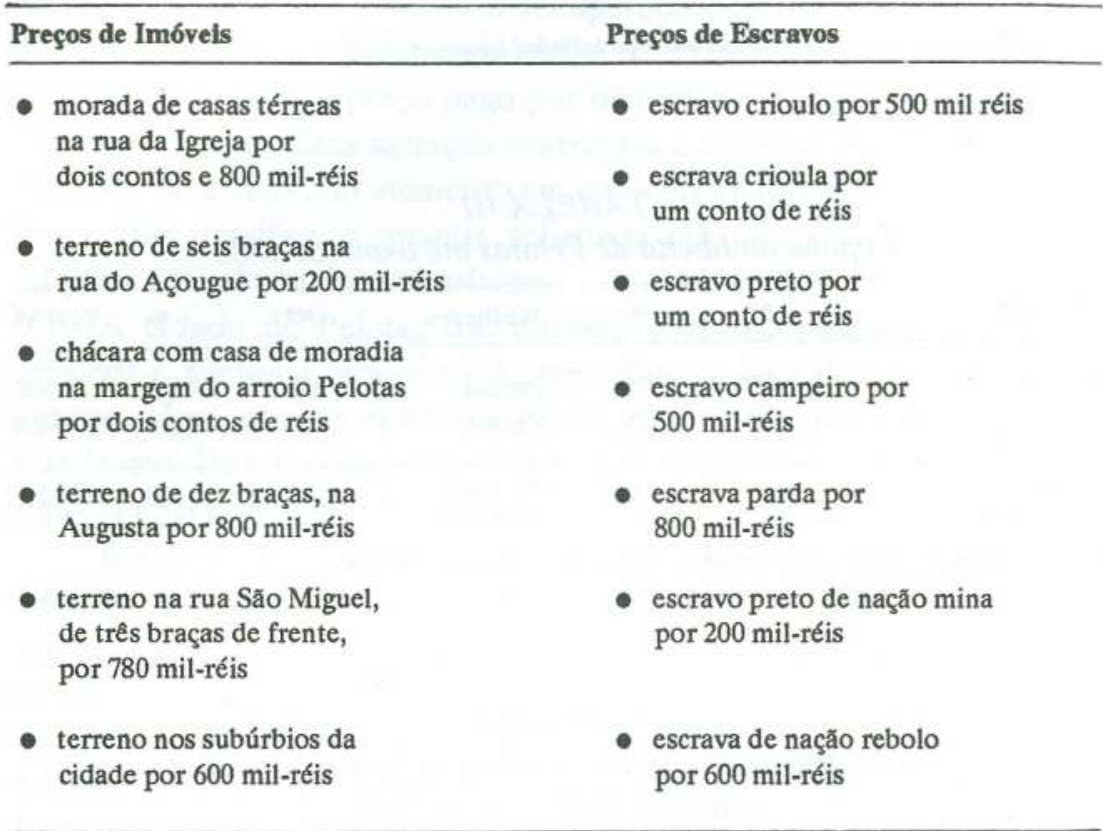

FONTE: Livro de Lançamentos Ordiários de Pelotas (cartas de alforrias) - Livro de Transmissōes de Pelotas (venda de terrenos). Local: Arquivo Público do RGS.

Apesar da pouca informação que dispomos, nossa documentação sugere que os cativos velhos fossem substituídos por outros mais jovens. Essa realidade parece ter sido uma das formas de o senhor se livrar dos escravos que perdiam o valor com o passar dos anos: [...] fica livre o meu escravo Maurício, nação gege, de idade de cinqüenta anos pouco mais ou menos, por me ter dado por ele outro escravo também de nome Maurício, nação nagana, de idade de vinte e cinco a trinta anos, e por assim ficar satisfeito de seu valor [...]." 


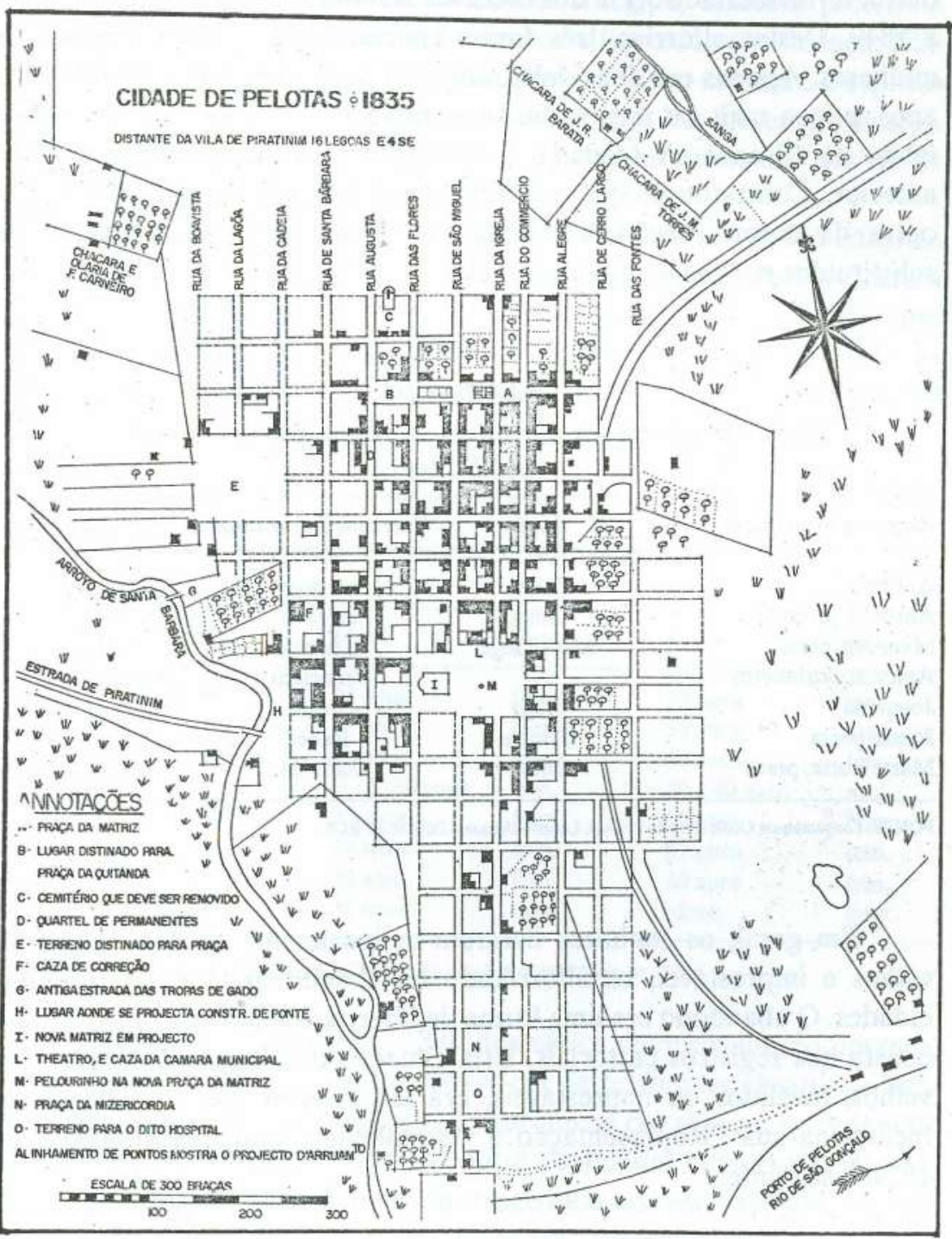


Segundo as cartas de alforrias, a substituição, de um cativo por outro, teria libertado 5,1\% dos escravos manumissos em Pelotas, de 1833 a 1849. Destas alforrias, três foram concedidas a homens e quatro a mulheres. Apenas em duas delas, constam as idades: uma crioula de 46 anos, pouco mais ou menos, foi substituída por uma escrava, de nação mina, de 18 anos. A segunda manumissão já foi citada no parágrafo anterior. Constatou-se que ao menos uma escrava foi substituída por outra da mesma nação. Também, percebeu-se que os cativos eram substituídos por outro do mesmo sexo.

\section{TABELAVI}

Escravos alforriados por substituição de outro em Pelotas

(1932-1849)

\begin{tabular}{lccc}
\hline Escravos Alforriados & Naçấo & Escravos Substitutos & Nação \\
\hline Antônio & Mina & escravo & - \\
Antônio, preto & Congo & escravo & Nação \\
Maurício, preto & Mina/Gege & Maurício & Nagana \\
Antônio, cozinheiro & - & Francisco & Moçambique \\
Joaquina & Jinga & Joana & Moçambique \\
Joana, preta & Crioula & Isabel & Mina \\
Maria Luiza, preta & Mina & Mônica & Mina \\
\hline
\end{tabular}

FONTE: Lançamentos Ordinários de Pelotas, Local - Arquivo Público do RGS.

Em geral, os senhores livraram-se igualmente de seus escravos, velhos e imprestávei, os alforriando ou abandonando pelas ruas das cidades. $\mathrm{O}$ abandono era uma forma de libertar o escravo. Porém ele não consta nos registros cartoriais. Esta situação de abandono de escravos velhos, inválidos ou imprestáveis, era tão comum que José Bonifácio incluiu na sua "Representação à Assembléia Geral Constituinte", de 1824, o seguinte:

"Art. $8^{2}$ - Todo senhor que forrar escravo velho, ou doente incurável, será obrigado a sustentá-lo, vesti-lo durante a vida, se o forro não tiver outro modo de existência; e no caso de o não fazer, será o forro recolhido ao hospital, ou casa de trabalho à custa do senhor."10 
Em 1854, um projeto de lei apresentado, à Câmara de deputados, por José Maurício Wanderley, barão de Cotegipe, também pretendia obrigar os senhores a sustentar os escravos alforriados por doença. Não foram possivelmente situações eventuais do cotidiano urbano e o espírito filantrópico dos senhores que fizeram com que tais leis fossem propostas. O grande número de escravos doentes ou inválidos existentes nos vários cantos das cidades 'ìmportunaria' a população livre.

Na cidade de Pelotas, de 1832 a 1849 , encontraram-se 156 alforrias registradas em cartório. Deste total, apenas 24 manumissões fizeram referências às idades dos cativos. Trinta e três por cento das alforrias com as idades conhecidas foram concedidas a escravos idosos. Devido às condições de vida imposta pela escravidão, inclui-se os cativos com 50 anos ou mais na categoria idosos.

\section{TABELA VII}

Idades dos escravos alforriados

\begin{tabular}{llllll}
\hline Idade & Sexo & Idade & Sexo & Idade & Sexo \\
\hline 2 anos & fem. & 28 anos & fem. & 50 anos & mas. \\
2 anos & mas. & 28 anos & fem. & 50 anos & mas. \\
4 anos & mas. & 31 anos & mas. & 50 anos & fem. \\
13 anos & fem. & + de 30 anos & fem. & 50 a 60 anos & mas. \\
menos & mas. & 35 anos & fem. & 50 anos & fem. \\
menos & fem. & 46 anos & fem. & 57 anos & fem. \\
20 anos & fem. & 48 anos & fem. & 60 anos & fem. \\
25 anos & mas. & 48 anos & mas. & idoso & mas. \\
\hline
\end{tabular}

FONTE: Lançamentos Ordinários de Pelotas (1832-1849). Local: Arquivo Público do RGS.

Segundo Kátia Mattoso: "Estudos sérios comprovam, no entanto, que o percentual de alforriados idosos em parte alguma ultrapassa $10 \%$ do total. A maioria dos senhores nâo jogavam na rua seus escravos inúteis [...]." ${ }^{12}$ Nossas pesquisas mostram outra realidade; como se pode ver, $33 \%$ das alforrias levantadas foram concedidas aos escravos que, devido às condições de existência servil da época, devemos considerar como idosos.

Nestes dados não foram computados a categoria abandono, na qual escravos velhos e doentes incuráveis, de qualquer idade, seriam inseridos. Se levarmos em consideração a alforria informal - abandono -, a 
porcentagem de manumissões de escravos velhos seria maior. $\mathrm{O}$ desenho "Negro Trovador", de Jean Debret, enfoca bem a realidade urbana, "[...] a desgraça de um velho negro indigente. A cegueira provocou a sua libertação, generosidade bárbara e muito comum no Brasil por causa da avareza. Seu pequeno guia carrega uma cana-de-açúcar, esmola destinada à sua alimentação habitual." ${ }^{13}$ Embora o desenho e o escrito foram inspirados no cotidiano do Rio de Janeiro, acreditamos que não tenha sido exclusiva daquela província.

\section{GRAVURA - NEGRO TROVADOR}

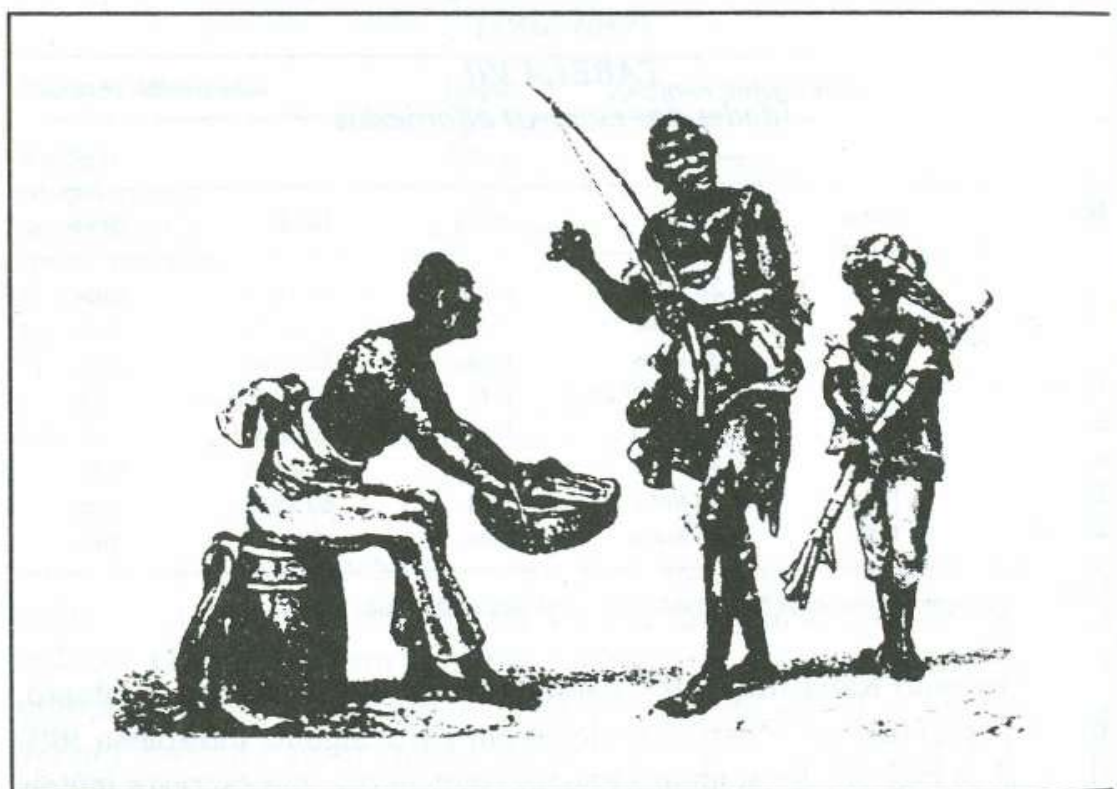

FONTE: DEBRET, Jean Baptiste. Viagem Pitoresca e Histórica ao Brasil. Tomo I. Săo Paulo, Livraria Martins/EDUSP, 1972 p. 253 .

Sobre a Revolução Farroupilha (1832-1849), realizaram-se vários estudos onde se reconheceu a presença do escravo no exército rebelde. Numa matéria do jornal do Rio de Janeiro, de Caldre e Fião, após os sustos, foi relatado: 
"A guerra civil no Rio Grande do Sul, de que sou testemunha, nos apresenta outro fato mui saliente: 'Os rebeldes [farrapos] chamaram ao seu exército os escravos, de que fizeram quatro batalhões e alguns esquadrões de cavalaria. Isso causou sérios sustos e arruinou muitas fortunas. Os escravos que não morreram nas batalhas ficaram mutilados e não serviram mais. Durante a guerra, os senhores sofreram estrondosas vinganças e conheceram bem o valor destes inimigos'."14

Em Pelotas, foi noticiado que 304 escravos haviam sido retirados de seus proprietários para se engajarem nas tropas revolucionárias, em troca de futura liberdade. ${ }^{15}$ Os roubos e fugas de cativos durante o governo farroupilha foram tão significativos que a Regência e o governo legalista denunciavam tais acontecimentos com freqüência. Chegaram a ordenar que fosse punido o escravo encontrado entre os rebeldes. Assim como também prometeram libertar todos os cativos que abandonassem os revolucionários. ${ }^{16}$

A Revolução Farroupilha teria influenciado no processo de manumissão da cidade de Pelotas. Pesquisas sobre este tema indicam que existiram "alforrias mais freqüentes nas fases de depressão e menos freqüentes nas fases de prosperidade". ${ }^{17} \mathrm{~A}$ documentação que levantamos, deste município, reafirma tal colocação.

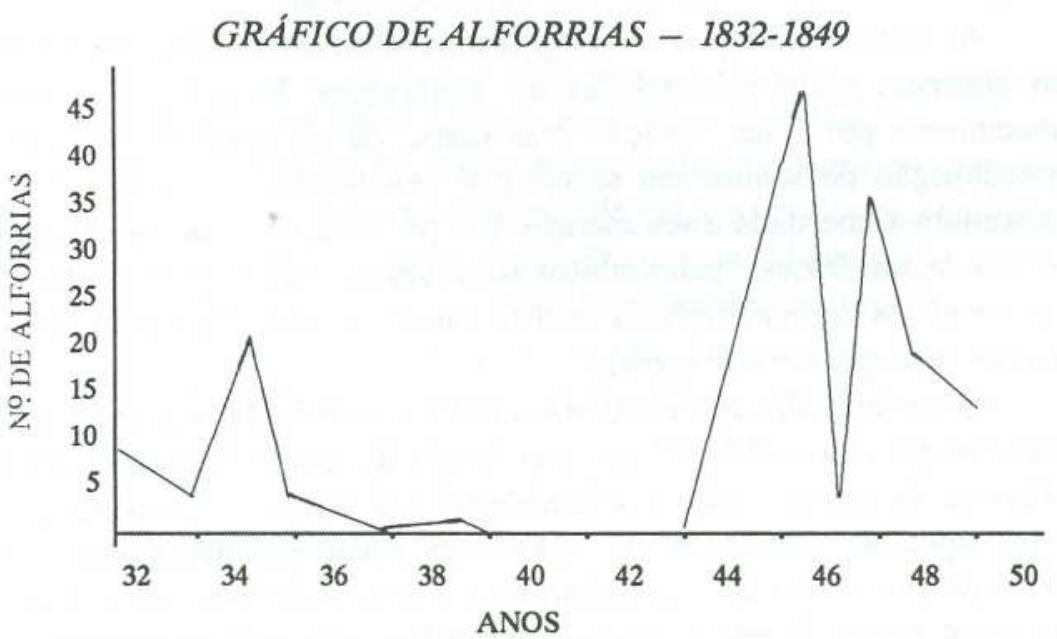

FONTE: Lançamentos Ordinários da cidade de Pelotas. Local: Arquivo Público do Rjo Grande do Sul (1832-1849). 
O número significativo de cartas de alforrias registradas no ano de 1845 - término da Revolução Farroupilha - deve ser devidamente analisado, visto que superou expressivamente os demais anos do período em estudo. Com o fim do governo revolucionário, o Rio Grande do Sul ficou fragilizado. Os diversos segmentos da sociedade gaúcha se encontravam em crise, os próprios estancieiros que com a revolução procuravam "assegurar as condições da dominação e do desenvolvimento da 'burguesia' pastoril gaúcha, ameaçada pelo centralismo a serviço do Sudeste", ${ }^{18}$ estavam numa situação delicada, pois haviam perdido a luta.

O processo revolucionário, que teve os grandes proprietários de terras e gados como classe dominante, nảo contou com a adesão de toda a sociedade gaúcha. Os farrapos "nảo tiveram o apoio da burguesia comercial e da classe média urbana em geral, da pequena propriedade agrícola familiar e dos estancieiros serranos e missioneiros. Os charqueadores se mantiveram indefinidos, negociando regularmente com ambas as facções". ${ }^{19}$

Esta situação abalou a vida política e sócio-econômica da Província. Neste contexto de crise, a venda de alforrias representaria uma forma de liquidez. Num total de 43 manumissões registradas no ano de 1845, 68\% foram onerosas. Em nenhum momento do período levantado encontraram-se alforrias tão bem pagas como neste ano: a crioula Ignacia pagou a quantia de um conto de réis por sua liberdade. O preto Pio Vianna pagou o valor de um conto de réis por sua carta de alforrias. ${ }^{20}$

As manumissões podiam ser gratuitas ou onerosas. Nas duas formas de alforrias, eram evidenciadas as declarações de gratidão e reconhecimento por bons serviços. Nas cartas de alforrias se percebe a preocupação de senhor em se mostrar benevolente, pelo fato de ter concedido a liberdade a seu escravo. Fez parte da retórica das cartas de liberdade, tais frases: "pelos muitos bons serviços que me tem prestado"; "por motivos de beneficiência confiro sua liberdade"; "em atenção aos muitos anos que me tem servido".

Quando as alforrias eram concedidas a prêmio, fatores como bons serviços, gratidão, fidelidade e benevolência do senhor se tornavam mais salientes. $\mathrm{O}$ não envolvimento de dinheiro nas manumissões evidenciava estes aspectos: "Digo eu Pedro de Oliveira abaixo assinado que entre os bens que possuo livres e desembargados é bem assim uma escrava preta de nome Joana, de nação mina, a qual pelos bons serviços que me tem 
prestado é minha vontade dar-lhe sua liberdade para sempre, da qual poderá gozar desde já como se livre tivesse nascido [...]."21

TABELA VIII

Alforrias pagas e gratuitas em Pelotas (1832-1849)

\begin{tabular}{lccc}
\hline Alforrias & $\mathbf{N}^{\circ}$ & $\begin{array}{c}\text { \% Sobre o Total } \\
\text { das Alforrias }\end{array}$ & $\begin{array}{c}\text { \% Sobre o Total } \\
\text { de Escravos }\end{array}$ \\
\hline Pagas & 73 & $46,8 \%$ & $\begin{array}{l}\text { Homens } 57 \% \\
\text { Mulheres } 50 \%\end{array}$ \\
Gratuitas & 83 & $53,2 \%$ & $\begin{array}{l}\text { Homens } 43 \% \\
\text { Mulheres } 50 \%\end{array}$ \\
\hline TOTAL & 156 & $100 \%$ & \\
\hline
\end{tabular}

FONTE: Livros de Lançamentos Ordinários da cidade de Pelotas (1832-1849). Local: Arquivo Público do RGS.

As manumissões onerosas, embora respeitassem o padrão das cartas de alforrias, onde era salientada a 'bondade' do senhor, destinavase a libertar qualquer escravo, fosse velho ou jovem, homem ou mulher, cativo doméstico ou não. $\mathrm{O}$ importante nesta questão era o pagamento do valor exigido pelo proprietário: a preta Joana, de cinqüenta anos de idade pouco mais ou menos, de nação nagô, escrava do senhor Joaquim E. Belgrado, pagou a quantia de 320 mil-réis por sua liberdade. ${ }^{25}$

A diferença percentual entre as manumissőes pagas ou gratuitas não chegou a ser significativa. Na cidade de Pelotas, as alforrias gratuitas superaram as onerosas por apenas $6,4 \%$. Na mesma cidade, a média geral das quantias pagas pelas cartas de liberdade foi de 350 mil-réis. Não havia diferença de preços quanto ao sexo; no que diz respeito às idades, a disparidade era expressiva. Enquanto um escravo idoso pagava por sua alforria 200 mil-réis, um cativo jovem chegava pagar pela mesma um conto de réis, como se pode constatar na Tabela IX. 
TABELAIX

Tabela de preços de escravos

\begin{tabular}{|c|c|c|c|c|}
\hline Sexo & Nacionalidade & Cor & Profissão & Preço \\
\hline mas. & crioulo & - & - & $500 \$ 000$ \\
\hline fem. & crioulo & - & - & $400 \$ 000$ \\
\hline mas. & crioulo & mulato & - & $400 \$ 000$ \\
\hline mas. & nação & - & - & $300 \$ 000$ \\
\hline fem. & $\operatorname{mina}$ & - & - & $150 \$ 000$ \\
\hline mas. & crioulo & - & sapateiro & 12 doublos \\
\hline mas. & - & - & - & 12 doublos \\
\hline fem. & - & parda & - & $100 \$ 000$ \\
\hline mas. & - & pardo & - & $400 \$ 000$ \\
\hline mas. & crioulo & - & - & $200 \$ 000$ \\
\hline fem. & calunda & - & - & $200 \$ 000$ \\
\hline mas. & moçambique & - & - & $307 \$ 200$ \\
\hline fem. & nação & preta & - & $100 \$ 000$ \\
\hline mas. & - & - & campeiro & $500 \$ 000$ \\
\hline fem. & crioula & - & - & $200 \$ 000$ \\
\hline mas. & congo & - & - & $8 \$ 150$ \\
\hline fem. & - & parda & - & $800 \$ 000$ \\
\hline mas. & - & pardo & - & $250 \$ 000$ \\
\hline fem. & - & parda & - & $102 \$ 400$ \\
\hline mas. & africano & preto & - & $100 \$ 000$ \\
\hline mas. & - & - & - & $200 \$ 000$ \\
\hline mas. & - & - & - & $100 \$ 000$ \\
\hline mas. & - & - & - & $38 \$ 400$ \\
\hline mas. & - & - & - & $280 \$ 000$ \\
\hline mas. & crioulo & - & - & $425 \$ 000$ \\
\hline mas. & - & - & - & $150 \$ 000$ \\
\hline fem. & - & - & - & $450 \$ 000$ \\
\hline fem. & crioula & parda & - & $250 \$ 000$ \\
\hline fem. & - & - & - & $250 \$ 000$ \\
\hline fem. & - & - & - & $250 \$ 000$ \\
\hline fem. & - & - & - & $600 \$ 000$ \\
\hline fem. & - & - & - & $280 \$ 000$ \\
\hline fem. & - & - & - & $200 \$ 000$ \\
\hline fem. & rebolo & - & - & $600 \$ 000$ \\
\hline mas. & crioulo & pardo & - & $576 \$ 000$ \\
\hline fem. & - & parda & - & 300 pesos prata \\
\hline mas. & crioulo & - & - & $576 \$ 000$ \\
\hline fem. & crioula & - & - & $900 \$ 000$ \\
\hline fem. & crioula & - & - & $1: 000 \$ 000$ \\
\hline mas. & - & preto & - & $1: 000 \$ 000$ \\
\hline fem. & crioula & - & - & $500 \$ 000$ \\
\hline mas. & pernambuco & - & $700 \$ 000$ & \\
\hline
\end{tabular}




\begin{tabular}{lcccc}
\hline Sexo & Nacionalidade & Cor & Profissão & Prȩ̧o \\
\hline fem. & crioula & preta & - & $500 \$ 000$ \\
fem. & nago & preta & - & $700 \$ 000$ \\
fem. & - & preta & - & $200 \$ 000$ \\
fem. & rebolo & - & - & $399 \$ 280$ \\
fem. & angola & preta & - & $332 \$ 800$ \\
fem. & congo & preto & - & $450 \$ 000$ \\
fem. & - & - & - & $400 \$ 000$ \\
fem. & mina & preta & - & $150 \$ 000$ \\
mas. & mina & preto & - & $200 \$ 000$ \\
fem. & crioula & preta & - & $400 \$ 000$ \\
fem. & nago & preto & - & $320 \$ 000$ \\
fem. & - & - & - & $950 \$ 000$ \\
mas. & mina & preto & - & $900 \$ 000$ \\
fem. & - & preta & - & $800 \$ 000$ \\
fem. & nagó & preta & - & $750 \$ 000$ \\
mas. & crioulo & - & - & $300 \$ 000$ \\
fem. & - & preta & - & $100 \$ 000$ \\
fem. & congo & preta & - & $700 \$ 000$ \\
fem. & crioula & - & - & $288 \$ 524$ \\
mas. & congo & preto & - & $600 \$ 000$ \\
fem. & crioula & - & - & $700 \$ 000$ \\
fem. & nago & preta & - & $300 \$ 000$ \\
\hline & & & &
\end{tabular}

FONTE: Lançamentos Ordinários de Pelotas (1832-1849). Local: Arquivo Público do RGS.

(-) significa indefinido.

As manumissōes gratuitas poderiam ser plenas, condicionais ou prometidas. Em Pelotas, a categoria plena foi a mais empregada. Num total de 83 manumissões gratuitas, 42 foram plenas, 39 prometidas e apenas duas foram condicionais. Não houve preferências quanto ao sexo. As alforrias gratuitas libertaram praticamente o mesmo número de homens e mulheres. Salientam-se apenas as duas manumissões condicionais outorgadas a cativas: Maria, preta, nação congo, de 60 anos mais ou menos, "desde hoje em diante livre, sem domínio [...] e tão somente com a obrigação de em quanto eu viva for morar em minha companhia". ${ }^{26}$ 
TABELAX

Alforrias gratuitas plenas, condicionais e prometidas de Pelotas

\begin{tabular}{lccc}
\hline Alforrias & Homens & Mulheres & TOTAL \\
\hline Plenas & 20 & 22 & 42 \\
Condicionais & - & 2 & 2 \\
Prometidas & 21 & 18 & 39 \\
\hline TOTAL & 41 & 42 & 83 \\
\hline
\end{tabular}

FONTE: Lançamentos Ordinários da Cidade de Pelotas (1832-1849). Local: Arquivo Público do RGS.

As manumissões onerosas, ao contrário das gratuitas, libertaram significativamente um maior número de mulheres do que de homens. Em Pelotas, de 1832 a 1849 , foram alforriados, mediante pagamento, 73 cativos. Deste total, 42 alforias foram destinadas a escravos de sexo feminino e 31 a de sexo masculino. $O$ que sugere uma maior capitalização por parte das mulheres escravas.

TABELAXI

Manumissões onerosas em Pelotas (1832-1849)

\begin{tabular}{lccc}
\hline Escravos & $\begin{array}{c}\mathbf{N}^{\circ} \text { de } \\
\text { Alforrias }\end{array}$ & $\begin{array}{c}\text { \% Sobre as } \\
\text { Alf. Pagas }\end{array}$ & $\begin{array}{c}\text { \% Sobre o } \\
\text { Total das Alf. }\end{array}$ \\
\hline $\begin{array}{l}\text { Homens } \\
\text { Mulheres }\end{array}$ & 31 & $42,5 \%$ & $19,8 \%$ \\
\hline TOTAL & 42 & $57,5 \%$ & $26,9 \%$ \\
\hline
\end{tabular}

FONTE: Lançamentos Ordinários da Cidade de Pelotas (1832-1849). Local: Arquivo Público do RGS.

Das 156 alforrias concedidas em Pelotas durante o período anteriormente citado, 84 foram outorgadas a mulheres e 72 a homens. Isso sabendo-se que o número de escravos homens superou significativamente a população cativa de sexo feminino. As mulheres representaram $53,8 \%$ das cartas de liberdade lançadas neste município. 
Em 92 cartas de alforrias constou a 'nacionalidade' dos escravos, o que corresponde a 58,9\%. Das manumissões que apontaram este dado, 39 foram concedidas a crioulos (escravos que nasceram no Brasil) e 53 a africanos. Porém se considerarmos os pardos e os pretos como pertencentes a nacionalidade crioula, teríamos bem mais crioulos alforriados do que africanos.

O resultado da soma das alforrias concedidas aos crioulos, pardos e pretos se contrapõe aos dados da Tabela I, onde o número de africanos superou significativamente os demais. Ao compararmos a Tabela I com a XII, percebe-se que os escravos africanos foram desfavorecidos no processo de manumissão.

\section{TABELA XII}

Nacionalidade dos Escravos

\begin{tabular}{|c|c|c|c|c|}
\hline Escravos & $\mathrm{N}^{\circ}$ & Escravos & $\mathrm{N}^{\circ}$ & $\begin{array}{l}\text { TOTAL DE } \\
\text { CRIOULOS, } \\
\text { PARDOS E }\end{array}$ \\
\hline Crioulos & 39 & Pardos* & 34 & PRETOS: \\
\hline Africanos & 53 & Pretos* & 7 & \\
\hline TOTAL & 92 & TOTAL & 41 & 77 \\
\hline
\end{tabular}

FONTE: Lançamentos Ordinários da Cidade de Pelotas (1832-1849). Local: Arquivo Público do RGS.

- Consideramos exceçōes, pois se referem a cor.

As charqueadas, base da economia de Pelotas, fundamentaram-se na mão-de-obra escrava e absorveram grande parte da população cativa da cidade. Possivelmente os africanos introduzidos em Pelotas, durante a primeira metade do século passado, foram destinados para a indústria do charque. Que devido à necessidade do braço escravo, acabou dificultando a concessão de alforrias. 
TABELA XIII

Escravos africanos

\begin{tabular}{lccc}
\hline Nacionalidade & Homens & Mulheres & TOTAL \\
\hline Congo & 8 & 2 & 10 \\
Mina & 6 & 6 & 12 \\
Moçambique & 4 & - & 4 \\
Cabinda & 2 & 1 & 3 \\
Ginga & - & 1 & 3 \\
Nagô & 1 & 4 & 5 \\
Benguela & 2 & 3 & 5 \\
Angola & - & 2 & 2 \\
Rebolo & 1 & 4 & 4 \\
Gege & 1 & - & 1 \\
Moange & - & 1 & 1 \\
Cassange & - & - & 4 \\
Nação & 4 & & 1 \\
\hline
\end{tabular}

FONTE: Lançamentos Ordinários de Pelotas. Local: APRGS.

Dos 156 escravos alforriados em Pelotas, 14 possuíam dois nomes. Destes cativos, seis eram mulheres e oito homens, significando 9,6\% sobre o total: Joaquina Maria, Maria do Bomfim, Maria Joana, Maria Luisa, Maria Dondá, José Branco, João Antônio, Antônio Baptista, Antônio da Paixão, Pio Viana, Joaquim Machado, Joaquim Conde, José Paixão.

Os nomes de mulheres escravas, que mais foram citados nas cartas de alforrias: Maria, Joana, Joaquina, Luisa e Rita. Os nomes mais usados nos cativos do sexo masculino: João, Joaquim, Antonio, José e Francisco.

Ao analisarmos os proprietários de escravos referidos nas manumissões, observa-se que a maioria eram homens. Estes dados não são surpreendentes, pois reafirmam a estrutura patriarcal da sociedade colonial e imperial brasileira. Percebeu-se que as senhoras e os casais proprietários de escravos alforriaram mais mulheres do que homens. Possivelmente o trabalho domésticos tenha sido um fator importante para este favorecimento, pois este serviço possibilita um relacionamento mais próximo entre senhoras e escravas. 
TABELA XIV

Proprietários de escravos em Pelotas (1832-1849)

\begin{tabular}{lccc}
\hline Proprietários & $\mathbf{N}^{\bullet}$ & $\begin{array}{c}\mathbf{N}^{\bullet} \text { de Escravos } \\
\text { Alforriados }\end{array}$ & $\begin{array}{c}\mathbf{N}^{\circ} \text { de Escravas } \\
\text { Alforriadas }\end{array}$ \\
\hline Homens & 87 & 44 & 44 \\
Mulheres & 38 & 21 & 30 \\
Casais & 11 & 3 & 11 \\
Clero & 2 & 1 & 1 \\
Familia & 1 & - & 1 \\
\hline TOTAL & 139 & 69 & 87 \\
\hline
\end{tabular}

FONTE: Lançamentos Ordinários de Pelotas (1832-1849). Local: Arquivo Público do RGS.

\section{Conclusões}

As manumissões corresponderam tanto aos interesses dos escravos, que viam nela uma das formas de obterem a liberdade, como aos dos senhores, que através da concessão de alforrias poderiam estimular a fidelidade de seus cativos. As cartas de liberdade, também, representaram um lucro suplementar aos proprietários. Muitas vezes, com o valor pago por uma alforria se adquiria um escravo novo ou, até mesmo, um imóvel urbano. Da mesma forma, as alforrias beneficiaram os senhores, na medida em que lhes possibilitaram livrar-se de seus escravos velhos ou imprestáveis de qualquer idade.

Embora a população escrava do sexo masculino tenha sido superior a feminina, foram alforriados mais mulheres do que homens. Possivelmente, a escravidão doméstica tenha influenciado nesta questão, visto que a maior parte dos serviços caseiros era realizado por escravas. Sabe-se que os cativos domésticos gozavam de preferência para realização das manumissões, em virtude de certa aproximação que poderia vir a existir entre senhores e escravos desta categoria.

As alforrias poderiam ser concedidas gratuitamente ou mediante pagamento. Nas duas formas, era explícito a ideologia senhoral, sempre com o objetivo de mostrar a 'bondade', a 'benevolência', do senhor. Mesmo nas cartas de liberdade onerosas, onde se chegava a pagar 
significativas somas, a 'cortesia' do proprietário era evidenciada. As manumissōes gratuitas, condicionais e prometidas tendiam a estimular a lealdade dos cativos para com os senhores.

No início da década de 30 do século passado, mais da metade da população escrava de Pelotas era constituída de cativos de nacionalidade africana. Porém no momento da concessão de alforrias, os pardos e crioulos foram priviligiados. Os escravos africanos, possivelmente, foram conduzidos para as charqueadas, onde a mão-de-obra cativa era fundamental. Devido a isso, as cartas de alforrias foram outorgadas em menor número em relação a escravidão doméstica ou urbana.

O processo de manumissão em Pelotas, foi influenciado pela Revolução Farroupilha. Sabe-se que em períodos de crise eram alforriados mais escravos do que em momentos de prosperidade. No ano de 1845 , término do episódio separatista, o número de cativos manumissos foi superior aos demais anos. Sendo que a maior parte das cartas de liberdade foram concedidas mediante pagamento, o que sugere a descapitalização do cativo em favor do senhor, num período em que a elite gaúcha se encontrava arruinada devido aos sucessos farroupilhas.

\section{Notas}

1. GORENDER, Jacob. O Escravismo Colonial. 4.ed. Rev. e ampl. Săo Paulo, Àtica, 1985. p.353.

2. Ibidem. p.352.

3. Lançamentos Ordinários de Pelotas (1832-1849). Local: Arquivo Público do RGS. Nesta e nas outras cartas de alforrias foi modernizada a ortografia.

4. Ibidem.

5. Cf. GORENDER, Jacob. Op. cit. p.165-85.

6. Ver: CORSETTI, Berenice. Estudos da Charqueada Escravista Gaúcha no Século XIX. Dissertação de Mestrado da Universidade Federal Fluminense, Niterói, 1983; BAKOS, Margaret Marchiori. RS: Escravismo \& Abolição. Porto Alegre, 1Mercado Aberto, 1982; MAESTRI FILHO, Mário José. O Escravo no Rio Grande do Sul. A charqueada e a gênese do escravismo gaúcho. Porto Alegre, EST-SLB; Caxias do Sul, EDUCS, 1984.

7. GORENDER, Jacob. Op. cit p.357.

8. Lançamentos Ordinários de Pelotas. Op. cit.

9. Ibidem.

10. FREITAS, Décio. Escravidảo de Índios e Negros no Brasil. Porto Alegre, EST/ICP, 1980. p.124.

11. GORENDER, Jacob. Op. cit. p.355.

12. MATTOSO, Kátia. Ser Escravo no Brasil. 2.ed. São Paulo, Brasiliense, 1982. p.186.

13. DEBRET, Jean Baptiste. Vlagem Pitoresca e Histórica ao Brasil. Tomo I. São Paulo, Livraria Martins/EDUSP, 1972. p.253. 
14. Caldure e Fião: Apud: BAKOS, Margaret Marchiori. "A Escravidão Negra e os Farroupilhas". In: FREITAS, Décio et alli. A Revolução Farroupilha: História \& Interpretação. Porto Alegre, Mercado Aberto, 1985. p.91.

15. Ibidem. p.90.

16. Ibidem. p.91.

17. GORENDER, Jacob. Op. cit. p.354.

18. FREITAS, Décio et alli. Op. cit. p.116-117.

19. Ibidem. p.117.

20. Lançamentos Ordinários de Pelotas (1832-1849). Local: Arquivo Público do RGS.

21. Ibidem.

22. Ibidem.

23. Ibidem.

24. Ibidem.

24. Ibidem.

25. Ibidem.

26. Ibidem. 